\title{
The Role of God's Mighty Acts in Joel: \\ The Book of Joel as an Example of Trauma Literature
}

\author{
IBOLYA BALLA \\ Pápa Reformed Theological Seminary \\ karib34@hotmail.com \\ ORCID: 0000-0002-0643-725X
}

\begin{abstract}
The Book of Joel abounds in the descriptions of God's mighty acts, including his interventions in the workings of nature and the unfolding historical events in the life of Israel and the so-called heathen nations. It has long been recognized that these acts are important in structuring the book as a whole. They can be labelled as negative or positive for the life of Israel, depending on which part of the book we interpret. In the final form of the work there is a centreline between its two major parts $(1: 1-2: 17 ; 2: 19-4: 21)$, separating the descriptions of divine punishment and lament from the accounts of restoration and joy when it comes to the relationship of the covenant community with God: "Then the Lord became jealous for his land, and had pity on his people" (Joel 2:18). This verse also serves as an introduction to $2: 19-4: 21$. What has not yet been examined in detail, however, is that the descriptions of God's working in the nations' history and in nature can help read the book from the viewpoint of trauma/crisis and tenacity. In the midst of crises Israel's only hope is to repent and turn to the Lord to have mercy. In repentance, the prophet's resilience and compassion is also significant; his words are handed down to us in a form that resembles the terminology, mood and theological teaching of certain lament psalms of the Hebrew Bible, yet representing the tradition of the day of the Lord especially important in prophetic literature. This paper aims at investigating the Book of Joel from the perspective of trauma and tenacity with a view to the scriptural allusions the author employs.
\end{abstract}

KeYworDs: Joel, Trauma, Tenacity, Resilience, Day of the Lord, Mighty Acts

\section{Introduction: Dating, Author and Structure of the Book of Joel}

It is accepted by most scholars that the Book of Joel is a postexilic work, according to which the leaders of the nation are the priests and the elders. ${ }^{1}$ Joel $4: 4$ implies that Sidon and Tyre have not yet been destroyed, therefore the attack of Artaxerxes III in 343 BC and of Alexander the Great in 332 BC can be taken

1 Joel 2:7-9 may imply that the walls of Jerusalem have been rebuilt. While Joel 4:6 refers to the Greeks, they are not yet necessarily the ruling powers. 
as a terminus ante quem regarding the composition of at least some parts of the book, if not all of it. ${ }^{2}$ Its author knew the traditions of a number of earlier prophets, such as Obadiah, whose work is dated to between the end of the $6^{\text {th }}$ century and the beginning of the $5^{\text {th }}$ which is the terminus post quem regarding the composition of Joel. It is probable that Joel follows not only Obadiah, but also Malachi, perhaps as the last within the Twelve to be composed, after 480-470 BC, or perhaps following the work of Nehemiah (cca. 450 BC), but before $343 \mathrm{BC}^{3}$ The author is a prophet of Judean origin - perhaps from the city of Jerusalem - who is familiar with the cult in the capital. The interest in sacrifices, offerings, in general in the priestly offices is characteristic of his book (1:9.13; $2: 14.17) .{ }^{4}$ These are general statements and do not necessarily imply that he was of priestly origin. He cannot be viewed as a peripheral or marginalized prophet only criticizing the priesthood, rather a prophet connected to the temple and attached to the priestly circles of Jerusalem by way of ideology. This is supported by the cultic elements of his oracles. ${ }^{5}$

In terms of content, there is a centreline (2:18) between 1:1-2:17 and $2: 19-4: 21$, separating the descriptions of divine judgment on Israel from the accounts of her restoration. There is a symmetry between the two main parts, expressed by corresponding ideas and images: Joel 2:21-27 describes the restoration of the conditions depicted in 1:4-20;4:1-17 details events of the day of

2 If Joel 4:4-8 was composed later than its context (4:1-16), the reference to these cities is helpful only in dating 4:4-8. A detailed discussion of the unity and composition of the book is beyond the scope of present study. For a literature review of the question, see among others: L.C. Allen, The Books of Joel, Obadiah, Jonah and Micah (NICOT; Grand Rapids, MI: Eerdmans 1976) 25-28; D.D. Pettus, A Canonical-Critical Study of Selected Traditions in the Book of Joel (PhD Dis. Liberty University, Waco, TX 1992) 31-40; M.A. Sweeney, "The Place and Function of Joel in the Book of the Twelve," Thematic Threads in the Book of the Twelve (eds. P.L. Redditt - A. Schart) (BZAW 325; Berlin New York: De Gruyter 2003) 136-137; W.S. Prinsloo, The Theology of the Book of Joel (BZAW 163; New York: De Gruyter 1985) 2-5 and H.W. Wolff, Dodekapropheton. II. Joel und Amos (BKAT 14; Neukirchen-Vluyn: Neukirchener 1969) 6-8.

3 Joel 2:11 is similar to Mal 3:2, Joel 3:5b to Obad 17a, Joel 4:3 to Obad 11, Joel 4:19 to Obad 10, while Joel 3:4b is identical to Mal 3:23b. See also J. Limburg, Hosea-Micah (IBC; Atlanta, GA: Knox 1988) 58; Wolff, Dodekapropheton, II, 4; E. Achtemeier, "The Book of Joel. Introduction, Commentary, and Reflections," NIB VII, 299-336; E.D. Mallon, "Joel, Obadiah,” The New Jerome Biblical Commentary (Englewood Cliffs, NJ: Prentice-Hall 1990) 399-400; J.J. Collins, Introduction to the Hebrew Bible (Minneapolis, MN: Fortress 2004) 420; J. Barton, Joel and Obadiah. A Commentary (Louisville, KY: Westminster John Knox 2001) 14-18. For a summary of the views on dating Joel, see also Prinsloo, The Theology of the Book of Joel, 5-10; D.W. Baker, Joel, Obadiah, Malachi (NIV Application Commentary; Grand Rapids, MI: Zondervan 2006) 24-26; J.A. Thompson - N.F. Langford, "The Book of Joel. Introduction, Exegesis and Exposition," IB VI, 727-728; G.W. Ahlström, Joel and the Temple Cult of Jerusalem (VTSup 21; Leiden: Brill 1971) 111-129.

4 J.T. LeCureux, "Joel, the Cult, and the Book of The Twelve," Priests and Cults in the Book of the Twelve (ed. L.-S. Tiemeyer) (ANEM 14; Atlanta, GA: SBL 2016) 65-79.

5 See also D.L. Petersen, The Prophetic Literature. An Introduction (Louisville, KY: Westminster John Knox 2002) 182; LeCureux, "Joel, the Cult, and the Book of The Twelve," 68-69. 
the Lord similar to those in $2: 1-11 ; 3: 1-5$ is connected to the repentance described in 2:12-17. The theme of hope appears in 2:12-17, which is the direct prelude to the announcement and justification (2:18) of mercy and restoration. ${ }^{6}$ In the canonical form of the book, the eschatological and apocalyptic themes are an integral part of the work, embedded into the theme of the day of the Lord that serves as a thematic bridge. According to Cook, "Joel's apocalyptic texts clearly stem from the pro-temple priestly center of postexilic society." "

\section{Descriptions of Trauma}

One of the reasons why it is difficult to read the Book of Joel is that the author blends the vision and sound effects in order to express the magnitude of the calamities suffered by Israel. One can almost see the devouring locusts in chapter 1 and hear the steps of the unstoppable invading army in chapter 2. From 1:4 to $1: 12$ - in the context of 1:2-12 - we find the description of two afflictions which are intertwined; they are interrupted by the exhortation to lament and mourn in v. 5., 8. and 11. The theme of lament, however, continues into the next pericope which begins with vv. 13-14. The afflictions in the first pericope are the locust invasion and the drought. The focus is especially on the countryside. It is difficult to translate the four Hebrew words describing the insects causing the suffering for Israel. Perhaps a full life cycle of the locust is described here, ${ }^{8}$ or by listing four different names, the author simply emphasizes the completeness of the devastation. ${ }^{9}$ A similar picture is found in Exod 10:5: "They shall cover the surface of the land, so that no one will be able to see the land. They shall devour the last remnant left you after the hail, and they shall devour every tree of yours that grows in the field" (NRSV). The terms "to relate," "to tell its account"

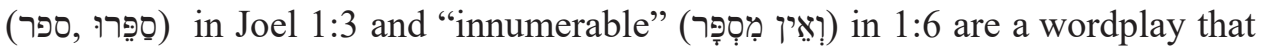
creates a parallel within the text. This didactic element about the transmission of these events to future generations may also be a reference to the wider context found in Exodus 10, where Moses was instructed by Yahweh to transmit the knowledge of his great judgments against Egypt to the following generations. The divine action of hardening the heart of Pharaoh (Exod 10:1) was for the purpose of multiplying Yahweh's miraculous judgments which the Israelites were to

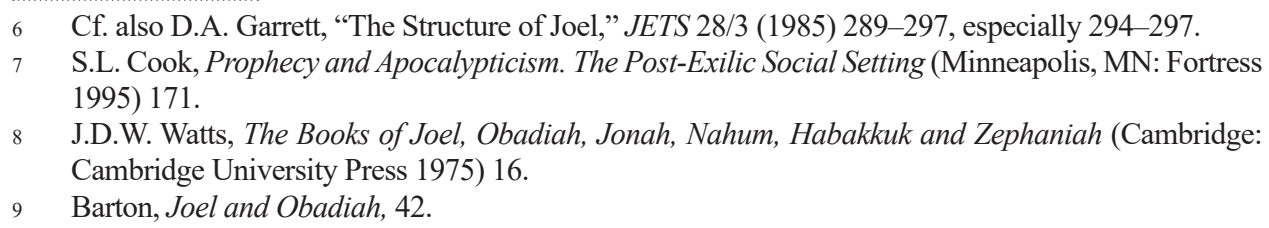

8 J.D.W. Watts, The Books of Joel, Obadiah, Jonah, Nahum, Habakkuk and Zephaniah (Cambridge: Cambridge University Press 1975) 16.

9 Barton, Joel and Obadiah, 42. 
recount to their children, so that their posterity would come to the knowledge of Yahweh as part of a national consciousness. ${ }^{10}$

In Joel 1:2-12 the produce falling victim to the invasion of the locust includes the most precious: vine and fig. The former provided not only drink but also medicine, while the latter was used as food for both humans and animals. The accompanying drought also means devastation for both humans, and fire makes destruction complete. Joel 1:19-20 also confirms that humans and animals share in the misfortunes.

In 2:1-11 the theme of judgment continues and the focus is on the city as opposed to chapter 1. The expression "Blow the trumpet in Zion; sound the alarm on my holy mountain!" (NRSV) in Joel 2:1 makes it clear that what follows is part of the prophecy concerning the day of the Lord. As in Josh 6:5, where the trumpet signifies battle, it is God who initiates the blowing of the trumpet in Joel 2:1. Although the invaders are called the northern army (2:20), Zion is the place from where devastation ultimately originates (see also Amos 1:2). ${ }^{11}$ Light (2:10), movement, sounds (2:5), verbs describing running, proceeding, jumping are among the poetic devices emphasizing that the army is unstoppable. ${ }^{12}$ The result of their invasion is wilderness and desolation. When God acts in the interest of his people - as during the conquest - one of the elements of victory is that He causes turmoil, terror among enemy lines (e.g. Exod 23:28; Deut 7:20; Josh 24:12). In Joel 2:1-11 it is Israel that suffers affliction, and her enemy is ordered, cannot be confused or disoriented: it is simply unstoppable. Joel 2:11 makes it clear that the army executes the command of God, as the judgment in connection with the day of the Lord: "The Lord utters his voice at the head of his army; how vast is his host! Numberless are those who obey his command" (NRSV).

While some of the images in Joel 2 resemble those of chapter 1 - the locusts are similar to the head of the horses - it is probable that the author did not simply intend to continue the topic of the locust invasion and the ensuing

10 As John Strazicich (Joel's Use of Scripture and the Scripture's Use of Joel. Appropriation and Resignification in Second Temple Judaism and Early Christianity [BibInt 82; Leiden - Boston, MA: Brill 2007] 72) notes: "In this instance, the function of the recognition formula was not for the Egyptians but for the benefit of" Israel. "This was intrinsically associated with instructing each new generation of Yahweh's great deeds, which he performed on their behalf."

11 Its name here forms an inclusio with Joel 4:17 (holy mountain of God). It may be, that Joel 4:17 was the conclusion of the original book of Joel, before the independant material in Joel 4:18-21 was added, or 4:17 may have been a link between 4:16 and 4:18-21 if we consider v. 16 the original ending of the book.

12 Note the inclusio in Joel 2:1-11: the first two verses are parallel with the last two verses in terms of content and imagery. The trumpet is blown by the command of God $(2: 1)$; the Lord utters his voice (2:11); the inhabitants of the land tremble (2:1); the earth quakes, the heavens tremble (2:10); the day of the Lord is accompanied by darkness, gloom, clouds and thick darkness (2:2); the sun and the moon are darkened, and the stars withdraw their shining (2:10); the attacking army is great and powerful (2:2 and 2:11). 
drought and fire. Rather, the images of devastation originating from God influenced the composition of the affliction in $2: 1-11$. There is a development between chapter 1 and 2:1-11, since the latter contains an apocalyptic description of a destructive, unstoppable army. In ushering in the day of the Lord, the latter is pointing towards events more frightening, more devastating than the previous ones, therefore the images of especially 1:4.6-7 pre-figure and are superseded by those in 2:1-11. The connection between them is typological in nature. It is obvious that the prophet sees in both chains of events the workings of God in history and nature, some of which are completed, while some others are still to come, and they are all connected with the coming day of the Lord.

\section{The Cause of Trauma and Its Relation to the Day of the Lord}

In the midst of this description, following the call to lament in 1:13-14 there is an important statement: "Alas for the day! For the day of the Lord is near, and as destruction from the Almighty it comes." (Joel 1:15, NRSV) As the post-exilic generations interpreted it, this situation was a sign that God was not with them (Joel 2:17; Hag 1:13; 2:5). ${ }^{13}$ While dressed in ordinary images of natural calamities, these pictures express a direct chain of act and consequence and leave no doubt according to the canonical form of the book that the trauma is the result of Israel's acts and judgment is deserved for her sins. While in many prophetic books we read about what Israel did to deserve punishment, ${ }^{14}$ here we can mainly conjecture it. The author of Joel affirms the theology of retribution expressed in deuteronomic theology. Although most of the first two chapters contain the description of the affliction that Israel experiences, there are statements at strategically important positions affirming that affliction comes from God (e.g. 2:1.11.18.27), and ultimately the cause of the trauma is sinful Israel. All this is embedded in the overarching theme of the day of the Lord, so important a topic in Joel.

13 T. Ganzel, "The Shattered Dream. The Prophecies of Joel. A Bridge between Ezekiel and Haggai?," Perspectives on Hebrew Scriptures (ed. E. Ben Zvi) (Piscataway, NJ: Gorgias 2013) VIII, 10; J.L. Crenshaw, "Who Knows What YHWH Will Do? The Character of God in the Book of Joel," Fortunate the Eyes That See. Essays in Honor of David Noel Freedman in Celebration of His Seventieth Birthday (eds. A.B. Beck et al.) (Grand Rapids, MI: Eerdmans 1995) 196: "Experience failed to confirm traditional belief. Faced with discontinuity between confessional statements about divine compassion and the circumstances confronting Judeans in his day, Joel strove valiantly to hold together competing views of YHWH's nature."

14 E.g. Isa $1: 4.23 ; 2: 6-8 ; 5: 8.11-12 ; 10: 1-2 ; 28: 7-8 ;$ Jer 2:5-8.13; 3:20; 5:4-14.18-31; 7:16-20; 17:1-8; 23:1-2; Ezek 7:10-11; 8 (passim); 13 (passim); 14:4; 16:15-34; 20 (passim); 22 (passim); 23:1-21 (passim); Hos 2:4-15; 4; 5:2-5.10-12; 6:7-10; 7.1-15; Amos 2:6-16; 3:9-10; 4:1-2.4-5; 5:10-12; 6:1.4-6.12; 8:4-6; Mic 2:1-2; 3:2-3.5.9-11; 7:3.6; Hab 1:1-5.13-17; 2:5-20; Zeph 1:5-6.8-9; 3:1-5 etc. 
In describing the day of the Lord, Joel probably builds on all of the following material: Amos 5:18-20; Isa 13:6.9; Ezek 13:5; Zeph 1:7.14-16; Obad 15; Mal 3:23, among which Amos was the first to formulate the term in this way. ${ }^{15}$ By the time of Joel the tradition probably incorporates all or most of the following notions: war, theophany, cultic lamentation, judgment on the covenant community, and a developing form of apocalypticism, which depicts Yahweh's abiding presence in Zion. ${ }^{16}$ The topic of the day of the Lord is connected with the theological tenet of covenant between God and Israel in Joel 1-2, and the topic of war in 2-4. Theophany is an important element in chs. 2-4. In ch. 4 the day of the Lord is described with semi-apocalyptic concepts of a new order and habitation, suggesting - as John Strazicich argues - that Yahweh's permanent dwelling in Zion is accompanied with changes of an eschatological topography. Yahweh as judge is appropriate to all references of the day of the Lord, but especially to the content of ch. 4. This theme is particularly apparent in and from Joel 4:2 onwards. In 4:2 the name of the site of the judgement on the nations, the "Valley of Jehoshaphat" contains the word שפט, "to judge." In this valley Yahweh judges the nations for their enslavement of Israel. This judgment is part of the theme of the coming day of the Lord in vv. 9-16 as will be seen below. ${ }^{17}$

Not necessarily signifying a specific duration of time, ${ }^{18}$ the day of the Lord refers to an event which acquires eschatological tones especially in 3-4. The inescapability of this day is stressed already in Amos where the term "darkness"

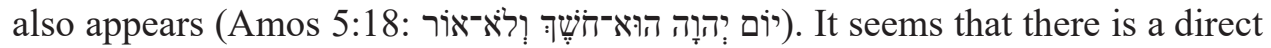
dependence on Zeph 1:14-16 which has very similar terms to those in Joel. In the former, the terminology describes Yahweh's day with eschatological language, containing the expectation of a theophany.

15 Strazicich (Joel's Use of Scripture, 84-85) points out that Joel uses the term "day of the Lord" five times in his book out of a total of 16 times in the Old Testament $(1: 15 ; 2: 1.11 ; 3: 4 ; 4: 14)$. He notes that "[t]he concept of the Day of Yahweh, though not original to him, is appropriated from other prophetic works, and its meaning is resignified contextually in conformity with his purposes."

16 Strazicich, Joel's Use of Scripture, 88. For the significance of important topics such as the day of the Lord for the composition of the Twelve and Joel's place in it, see J.D. Nogalski, "The Day(s) of YHWH in the Book of the Twelve," Thematic Threads in the Book of the Twelve (eds. P.L. Redditt - A. Schart) (BZAW 325; Berlin - New York: De Gruyter 2003) 192-213, especially 200-203; P.R. House, "Endings as New Beginnings. Returning to the Lord, the Day of the Lord, and Renewal in the Book of the Twelve," Thematic Threads in the Book of the Twelve (eds. P.L. Redditt - A. Schart) (BZAW 325; Berlin - New York: De Gruyter 2003) 313-338, especially 320-323; M. Beck, Der "Tag YHWHs” im Dodekapropheton. Studien im Spannungsfeld von Traditions- und Redaktionsgeschichte (BZAW 356; Berlin - New York: De Gruyter 2005), especially 140-201 and P.-G. Schwesig, Die Rolle der Tag-JHWHs-Dichtungen im Dodekapropheton (BZAW 366; BerlinNew York: De Gruyter 2006) especially 116-178.

17 Strazicich, Joel's Use of Scripture, 88-89.

18 It will not be discussed here that some of the interpreters understand the day of the Lord only as referring to a future event, while some others as including past events as well. For the overview of the topic, see Strazicich, Joel's Use of Scripture, 85-89. 
Zeph 1:14-16

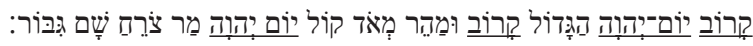

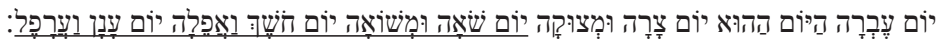

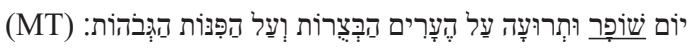

The great day of the Lord is near, near and hastening fast; the sound of the day of the Lord is bitter, the warrior cries aloud there.

That day will be a day of wrath, a day of distress and anguish, a day of ruin and devastation, a day of darkness and gloom, a day of clouds and thick darkness,

a day of trumpet blast and battle cry against the fortified cities and against the lofty battlements (NRSV).

Joel 2:1-2a

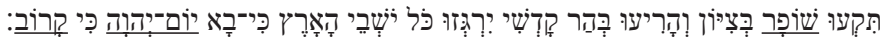

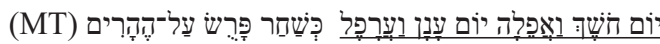

Blow the trumpet in Zion; sound the alarm on my holy mountain! Let all the inhabitants of the land tremble, for the day of the Lord is coming, it is near, a day of darkness and gloom, a day of clouds and thick darkness! Like blackness spread upon the mountains (NRSV).

As compared with Ezek 13:5, according to which the false prophets have no place of safety on the day of battle, Joel represents the faithful prophet, who calls for repentance and stands in the gap in the postexilic community $(1: 15$; $2: 1.12-17)$. Thus, the people's repentance could reverse more afflictions and calamities that would accompany the coming day of the Lord $(2: 14) .{ }^{19}$

In Isaiah 13 one encounters terminology that is filled with apocalyptic overtones, similarly to Joel 2. Joel's use of Scripture is significant in the reception of Isa 13:6.10 where we find a call to lament, and the content of some of their respective verses are similar:

Isa 13:6

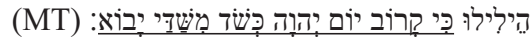

Wail, for the day of the Lord is near; it will come like destruction from the Almighty! (NRSV).

19 Strazicich, Joel's Use of Scripture, 93; see also J.L. Crenshaw, Joel. A New Translation with Introduction and Commentary (AB 24C; New York: Doubleday 1995) 129. 
Joel 1:15

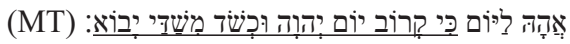

Alas for the day! For the day of the Lord is near, and as destruction from the Almighty it comes (NRSV).

Isa $13: 10$

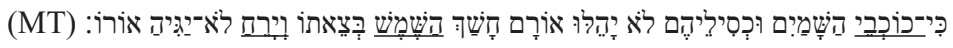

For the stars of the heavens and their constellations will not give their light; the sun will be dark at its rising, and the moon will not shed its light (NRSV).

Joel 2:10

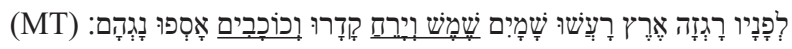

The earth quakes before them, the heavens tremble. The sun and the moon are darkened, and the stars withdraw their shining (NRSV).

Joel 4:15

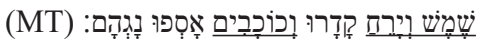

The sun and the moon are darkened, and the stars withdraw their shining (NRSV).

The day of the Lord according to these descriptions takes on cosmic dimensions typical of apocalyptic literature. It transpires on a day when the sun, moon and stars lose their brightness. The terror of the invading army of Joel 2:10 can only be described with images which in Joel 4:15 and Isa 13:10 portray great cosmic upheavals as Yahweh's warriors wage battle against Israel's enemies: the nations gathered in the Valley of Jehosphat (Joel) and Babylon (Isaiah). In the Joel text one of the ways to interpret the battle is that the people who are summoned to wage battle in 4:9-16 are not a human army but the heavenly host. While in Isa 13:1-22 the day of the Lord is instituted through human armies (the Medes, v. 17) which overthrow Babylon, apocalyptic terminology, astrological disturbances are associated with theophanic approach in judgment. The announcement of the day of the Lord according to Joel 2 formed the basis of communal lament. In this chapter Israel's fortunes have not yet turned, while the "day of the Lord" motif in Joel 4 points beyond the repentance of Israel to an age in which judge- 
ment is carried out on those that caused distress, trauma to God's elect at some stage in history. ${ }^{20}$ In the first part of the book - preceding 2,18 - Israel herself experiences turmoil and trauma, but due to her and her prophet's tenacity, faith and contrition on the one hand, and God's steadfast love, compassion and mercy on the other, there is a time when she will experience healing, blessings and joy, and her enemies' lot will in turn be trauma.

In the Book of Obadiah the day of the Lord is an event of war. However, it is an eschatological era in which Yahweh's kingdom extends its rule from Zion over Edom and Philistia (vv. 18-21). The day of the Lord, however, is not pictured in apocalyptic terminology, as in Joel 3-4. Obadiah focuses on reinstating the ancient boundaries of the nation as they were under King David, thus establishing God's rule in Zion, ${ }^{21}$ a concept that is also central to Joel's message (Joel 2:1; 3:5; $4: 16-17.21){ }^{22}$

\section{Reaction to/Solution of Crisis}

In Israel's restoration the prophet plays an important role. The source of resilience and tenacity is found in the possibility of repentance and in the covenant. It is expressed through the words and faith of the prophet. The expression in Joel 1:19 ("To you, O Lord, I cry," NRSV) interrupts the previous description of the suffering of the animal world. This demonstrates that the prophet is not a dispassionate, immovable witness of the unfolding events. He feels responsible for his nation, suffers with them and implores God on their behalf and with them. But what is the basis of his plea? Important theological teachings are found at important points of the book, representing Israel's major traditions, such as His fidelity to the covenant, His steadfast love, compassion and mercy for Israel. These are also the answers to the question of Joel 2:11: who can endure the day of the Lord? The basis of the prophet's hope is expressed in Joel 2:13b ("he is gracious and merciful, slow to anger, and abounding in steadfast love, and relents from punishing," NRSV) and Joel 2:14a ("Who knows whether he will not turn and relent," NRSV). The former has its parallel in Jonah 4:2b ("you are a gracious God and merciful, slow to anger, and abounding in steadfast love, and ready to

20 Graham S. Ogden (“Joel 4 and Prophetic Responses to National Laments," JSOT 26 [1983] 97-106) explores the relationship of national lament liturgy and prophetic oracles especially regarding Joel 4.

21 Strazicich, Joel's Use of Scripture, 94-95.

22 Outside of the prophetic literature Psalm 97 - as a hymn in honor of Yahweh's enthronement and universal eschatological rule - may also be in the background of the motifs used by Joel. See especially Ps 97:2-3: "Clouds and thick darkness are all around him; righteousness and justice are the foundation of his throne. Fire goes before him, and consumes his adversaries on every side" (NRSV). 
relent from punishing," NRSV), and the latter is the same in Hebrew as Jonah 3:9a ("Who knows? .. may relent and change his mind," NRSV). ${ }^{23}$ According to Jonah $4: 2 b$ - in the context of the Book of Jonah - the prophet is unable to identify with God's mercy towards Nineveh and presents a different prophetic attitude to that of Joel, who is not in the way of salvation but is an instrument of it. It appears that in Joel 2:13-14 the author cites well known formulaic expressions about God's character. ${ }^{24}$ The hope that there will be some, who will endure the day of the $\operatorname{Lord}^{25}$ according to Joel is based on these characteristics. For this reason, Israel must seek God and repent. In the dynamic relation of God and Israel repentance can influence God's decision and actions, and retribution will mean different things for the godly and the godless. The justification for it is

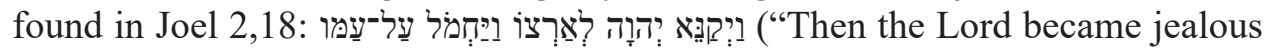
for his land, and had pity on his people," NRSV). This expresses in anthropomorphic terms one of the most important characteristics of the covenant relationship. God did not reject his people completely; he feels responsible for them, continues to love them. The verb ("to be jealous") is in the first line of the parallel in connection with "land"/ "country," while ("to feel compassionate," "to have pity") is connected with "people." They are both emotionally charged verbs, among which the first contains the concept of the 2. commandment as well. According to Joel, God hates sin, and forgiveness is dependant upon the repentance of Israel. God is also merciful, and penitence gives way to compassion.

It is important to note that the lament genre is combined with the concept of the day of the Lord in Joel. Indeed, the lament setting of the book of Joel can be detected both in the invitation to lament, and in the imagery the prophet uses in these calls. ${ }^{26}$ Arvid S. Kapelrud even proposed that Joel's book constituted a "psalm lamentation" followed by a salvation oracle. ${ }^{27}$ The association of funerary mourning and lament is appropriate to the concept of the day of the Lord in Amos 5, Ezekiel 30, and Isaiah $13-14,{ }^{28}$ because it deals with the notion of the military overthrow of nations in war. The inescapability of this day is also attached to the threat of exile in Amos 5:27. Joel exploits the liturgical theme of lament, incorporating it through the cult. As a result, the liturgical motif that

23 In Jonah 4:2b the speaker is the prophet himself, in Jonah 3:9a the king of Nineveh.

24 Tradition historical questions regarding Joel 2:13-14 and Jonah 3:9; 4:2 will not be discussed here in detail. It is probable that both authors knew and used these existing formulaic expressions and did not borrow it from each other.

25 See also Mal 3:2.

26 G.S. Ogden - R.R. Deutsch, A Promise of Hope. A Call to Obedience. A Commentary on the Books of Joel and Malachi (Grand Rapids, MI: Eerdmans 1987) 10.

27 A.S. Kapelrud, Joel Studies (Uppsala: Lundequist 1948) 9.

28 M.A. Sweeney, Isaiah 1-39 with an Introduction to Prophetic Literature (Grand Rapids, MI: Eerdmans 1996) 218. 
has been associated with the day of the Lord in Amos, Zephaniah, and Ezekiel is "recontextualized in Joel's highly liturgical text." 29

Apart from the passages noted above regarding Joel's use of the theme of the day of Yahweh, we should note that in the second call to lament in 2:15-17 he probably employs portions of Psalm 79 especially regarding the concept of Israel being the byword among the nations (Joel 2:17; Ps 79:4.10.12), and through the word "heritage" (Joel 2:17; Ps 79:1).

As noted above, in Joel 2,11 hope appears: "Truly the day of the Lord is great; terrible indeed - who can endure it?" (NRSV). Apart from this verse, Joel 2:18 is the turning point of the book from where the restoration of Israel is described. It first involves the material blessings of country/land, people in 2:18-27, in which we find the reversal of the afflictions of chapter 1 . Beyond this, restoration means that Israel will no longer be the byword or mockery of the foreign nations and will no longer have reasons to be ashamed (Joel 2:19). ${ }^{30}$

We also read about the removal of the northern enemy in Joel 2:20. Behind the allusion we may find concepts of Jeremiah 4-6 and Ezekiel 38-39. The topic of the enemy from the north in these passages is anchored both historically and eschatologically. The theme of the northern enemy in the Jeremianic texts has generally been interpreted historically, relating to the Babylonian kingdom (Jer 1:13-15; 4:6; 6:1), ${ }^{31}$ while in Ezekiel it is representative of an eschatological enemy (Ezek 38:14-16; 39:1-2). ${ }^{32}$

As a result of repentance and forgiveness, the children of Zion are to rejoice according to Joel (2:23). While not a lament psalm, here we may think of Psalm 126 in which the fortunes of Israel are also turned. It contains the term "Zion" and Yahweh's reassurance oracle of agricultural fecundity and renewal (cf. Joel 2:21-24). Concerning Joel's term of "early rain for your vindication" (2:23), the following biblical references can be taken into consideration: Lev 26:3-4; Deut 11:12-15; Jer 5:24 and Ps 84:7.33 Among them Deut 11:12-15 is especially important for understanding the traditions behind Joel's promise of salvation in 2:19 and 2:21-24, since Deut 11:14 contains the expression "your grain, your wine, and your oil" that is similar to that used in Joel 2:19 (cf. also Joel 2:24). Deut 11:14 and Joel 2:23 are also connected by the words "to give" and "late rain." The condition of God's maintenance of the land is obedience to

29 Strazicich, Joel's Use of Scripture, 96. Others argue that Joel drew part of the imagery from Exod 10:19 according to which God casts the locust into the Red Sea; see Allen, The Books of Joel, 89. S. Bergler, Joel als Schriftinterpret (BEATAJ 16; Frankfurt: Lang 1988) 265-266.

30 See also the lament of the individual in Psalm 42.

31 W. Brueggemann, A Commentary on Jeremiah. Exile and Homecoming (Grand Rapids, MI: Eerdmans 1998) 28.

32 Allen, The Books of Joel, 88-89.

33 Deut 11:12-15 is a key passage regarding Joel 2:19.21-24. The manner in which the passage in Deuteronomy focuses on the topic of land (v. 12), man (v. 14), and animals (v. 15) is noteworthy. 
his commandments (Deut 11:13) and turning to him in fasting and repentance (Joel 2:12-13.15-16). ${ }^{34}$ Due to the abundance of wine and oil it will also be possible to carry out cultic duties, such as offerings and sacrifices..$^{35}$

According to the teaching of the Book of Joel, the day of the Lord has much more in store for Israel than material blessings, as expressed in Joel 3:1-5. Joel 3:1 ("Then afterward I will pour out my spirit on all flesh," NRSV = 2:28) may refer to Ezek 39:29, where the pouring out of God's spirit is connected with the restoration from exile: ${ }^{36}$

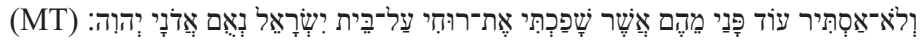

"and I will never again hide my face from them, when I pour out my spirit upon the house of Israel, says the Lord God" (NRSV).

Joel, however has "all flesh," instead of "house of Israel" as in Ezekiel. The use of this phrase would suggest an unparalleled universalism. For a universalistic interpretation of "all flesh" in Joel 3:1 - as Strazicich argues - one would need to assume that the nations appear in a salvific context in 3:5. However, Joel's message of salvation seems limited to the worshippers of Yahweh within Israel, especially if we take into account Joel 4:1-3 and 4:9-17 where the nations are enemies of Israel. The pouring out of God's spirit on all flesh is a "promise of pneumatic empowering for those who invoke the name of Yahweh in Zion to be delivered from slaughter on the Day of Yahweh." ${ }^{37}$

Behind the accompanying portents one may refer to several biblical traditions: elements in God's theophany (Exod 3:2; 2 Sam 22:13 = Ps 18:13; 2 Sam 22:9 $=$ Ps 18:9), or those associated with Moses in (Exod 4:21) or Moses and Aaron (Exod 11:10; see also Isa 8:18; 20:3). In the references to blood, fire and palm tree-like smoke we may see the concepts of Ezek 38:22 - which deals with the eschatological battle of God against Gog -, or that of Exod 7:20b ("and all

34 Strazicich, Joel's Use of Scripture, 188.

35 Joel 2:26 is similar to Deut 8:10. However, the former uses "to praise" (הלר), the latter employs "to bless" (פר) regarding God: "You shall eat your fill and bless the Lord your God for the good land that he has given you" (Deut 8:10, NRSV); "You shall eat in plenty and be satisfied, and praise the name of the Lord your God, who has dealt wondrously with you" (Joel 2:26, NRSV).

36 Strazicich, Joel's Use of Scripture, 208. See also Ezek 36:27-29: "I will put my spirit within you, and make you follow my statutes and be careful to observe my ordinances. Then you shall live in the land that I gave to your ancestors; and you shall be my people, and I will be your God. I will save you from all your uncleannesses, and I will summon the grain and make it abundant and lay no famine upon you" (NRSV) and Zeph 3:9: "At that time I will change the speech of the peoples to a pure speech, that all of them may call on the name of the Lord and serve him with one accord" (NRSV). For the outpouring of the spirit cf. also Isa 44:3; Ezek 37:14. For the eschatological work of the Spirit in the Book of Joel, see also W.A. VanGemeren, "The Spirit of Restoration," WTJ 50 (1988) 81-102, especially 90-96.

37 Strazicich, Joel's Use of Scripture, 209-210. 
the water in the river was turned into blood," NRSV). In the latter the verb

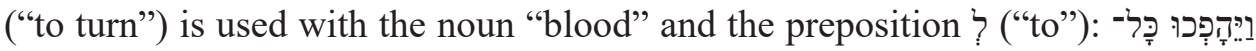

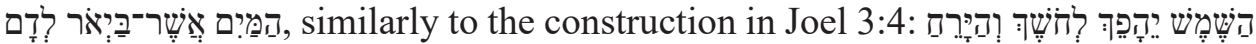
לְדָ ("The sun shall be turned to darkness, and the moon to blood," NRSV). As noted above, the language and images of the locust invasion of Joel 1 resemble those of Exod 10:5 that is also found in the context of the plague at the time of the Exodus. ${ }^{38}$ The events and signs described in Joel 1:4-12; 2:1-11 and 3:1-5 are all connected with the day of the Lord which means different things for those who repent and call on God's name and those who do not. Concerning these passages, there is a shift in emphasis throughout the book. The focus of the day of the Lord according to 1:4-12 is mainly the land/country of the chosen nation; it is specifically the countryside that suffers and the afflictions affect the cult as well. In 2:1-11 the focus is on the fortified city. Towards the end of this passage, however, the scope of the events broadens to include the cosmos (2:10), and in 3:1-5 the cosmic perspective is also apparent. The judgment on the nations according to 4:1-17 - as noted before - also forms part of the "day of the Lord" tradition and is portrayed by Joel through motifs and concepts known to and recontextualized by him. The eschatological battle or rather massacre is depicted with apocalyptic images, some of which are the reversal of those in Isa 2:1-5 and Micah 4:1-5. ${ }^{39}$ The motifs of 4:15 - appearing in 2:10 as well - also demonstrate that the theophany as part of the day of the Lord affects the entire cosmos. The Zion motif of 3:5 is taken up in 4:16, alluding to the language of Amos 1:2 ("And he said: The Lord roars from Zion, and utters his voice from Jerusalem; the pastures of the shepherds wither, and the top of Carmel dries up," NRSV). Amos 1:2 serves as an introduction to the oracles against the nations, while Joel 4:16 is part of the salvation oracles.

While God carries out his judgment on the nations, the final words of the book (4:18-21) describe his eschatological restoration of Zion with images of agricultural fecundity, probably building on Amos 9:11-15. ${ }^{40}$ Joel 4:18b may be a conflation of Gen 2:10 and Ezek 47:1-12 by combining the images of temple-river (Ezek 47:1-12), garden-river (Gen 2:10) with those of mountains dripping sweet wine and hills flowing with milk in order to describe the blessings of the day of the Lord for Judah. ${ }^{41}$

38 Strazicich, Joel's Use of Scripture, 214-216; See L.C. Allen, Ezekiel 20-48 (WBC 29; Dallas, TX: Word Books 1990) 207; Kapelrud, Joel Studies, 141; Allen, The Books of Joel, 100-101; Bergler, Joel als Schriftinterpret, 269. Isa 13:10 was already cited in connection with Joel 2:10 and 4:15.

39 Strazicich, Joel's Use of Scripture, 88-89.

40 Strazicich, Joel's Use of Scripture, 242. While Amos 9:11-15 is secondary to the Book of Amos, it was probably composed earlier than Joel 4:18-21.

41 Ahlström, Joel and the Temple Cult of Jerusalem, 94; Bergler, Joel als Schriftinterpret, 331; Strazicich, Joel's Use of Scripture, 243. 


\section{Summary}

In the canonical form of the Book of Joel the images of 1:2-12 and 2:1-11 - describing the devastation experienced by Israel - are closely connected. At the same time, the images of restoration in 2:18-27 and 3:1-5 are a direct continuation of $1: 2-2: 17$. The topics of trauma, resilience and restoration in the framework of the day of the Lord is an overarching theme connecting these chapters. According to the author, God is behind everything that happens to Israel, to her neighbours and to nature, all events can be placed in the web of His actions and workings in the universe. In the dynamic relation between God and Israel, God's actions can be motivated. Such belief is part of the belief in the covenantal relationship with him and serves as a source of resilience or tenacity of Israel and the prophet Joel. It prompts contrition, repentance and appeal to God for the turning of the fortunes of Israel. In this process the prophet plays an important role not only as a witness, a watcher, but also as a member of the community of the believers, being one with them, whose duty it is to implore God on their behalf. His faith in God and in covenant is significant, and it is expressed in the theological traditions handed down to and recontextualized by him. In this regard his relation to the cult is important. His acquaintance with Israel's lament traditions is also noteworthy and forms a characteristic part of his theological teaching. The lament character of the work is relevant for the question of the function of Joel's work in the community. He leads Israel on the path of repentance and restoration. As such, he is an example of the faithful, resilient prophet who expresses age-old Israelite traditions and tenets about God and covenant. He is both recipient and tradent of such traditions that - as concise confessions - may serve Israel to interpret and reinterpret her relationship with God in other, turbulent and traumatic situations in order to gain strength, to repent and to return to God. These traditions are suitable for liturgical use for future generations. Circumstances, locations can be changed, but the main message about the God who is "gracious and merciful, slow to anger, and abounding in steadfast love, and relents from punishing" (Joel 2:13, NRSV) is enduring. This makes the Book of Joel relevant for all ages.

\section{Bibliography}

Achtemeier, E., "The Book of Joel. Introduction, Commentary, and Reflections," The New Interpreter's Bible (Nashville, TN: Abingdon 1996) VII, 299-336.

Ahlström, G.W., Joel and the Temple Cult of Jerusalem (Supplements to Vetus Testamentum 21; Leiden: Brill 1971). 
Allen, L.C., The Books of Joel, Obadiah, Jonah and Micah (New International Commentary on the Old Testament; Grand Rapids, MI: Eerdmans 1976).

Allen, L.C., Ezekiel 20-48 (Word Biblical Commentary 29; Dallas, TX: Word Books 1990).

Baker, D.W., Joel, Obadiah, Malachi (NIV Application Commentary; Grand Rapids, MI: Zondervan 2006).

Barton, J., Joel and Obadiah. A Commentary (Louisville, KY: Westminster John Knox 2001).

Beck, M., Der "Tag YHWHs" im Dodekapropheton. Studien im Spannungsfeld von Traditions- und Redaktionsgeschichte (Beihefte zur Zeitschrift für die alttestamentliche Wissenschaft 356; Berlin - New York: De Gruyter 2005).

Bergler, S., Joel als Schriftinterpret (Beiträge zur Erforschung des Alten Testaments und des antiken Judentums 16; Frankfurt: Lang 1988).

Brueggemann, W., A Commentary on Jeremiah. Exile and Homecoming (Grand Rapids, MI: Eerdmans 1998).

Collins, J.J., Introduction to the Hebrew Bible (Minneapolis, MN: Fortress 2004).

Cook, S.L., Prophecy and Apocalypticism. The Post-Exilic Social Setting (Minneapolis, MN: Fortress 1995).

Crenshaw, J.L., Joel. A New Translation with Introduction and Commentary (Anchor Bible 24C; New York: Doubleday 1995).

Crenshaw, J.L., "Who Knows What YHWH Will Do? The Character of God in the Book of Joel," Fortunate the Eyes That See. Essays in Honor of David Noel Freedman in Celebration of His Seventieth Birthday (eds. A.B. Beck et al.) (Grand Rapids, MI: Eerdmans 1995) 185-196.

Ganzel, T., "The Shattered Dream. The Prophecies of Joel. A Bridge between Ezekiel and Haggai?," Perspectives on Hebrew Scriptures (ed. E. Ben Zvi) (Piscataway, NJ: Gorgias 2013) VIII, 157-178.

Garrett, D.A., "The Structure of Joel," Journal of the Evangelical Theological Society 28/3 (1985) 289-297.

House, P.R., "Endings as New Beginnings. Returning to the Lord, the Day of the Lord, and Renewal in the Book of the Twelve," Thematic Threads in the Book of the Twelve (eds. P.L. Redditt A. Schart) (Beihefte zur Zeitschrift für die alttestamentliche Wissenschaft 325; Berlin - New York: De Gruyter 2003) 313-338.

Kapelrud, A.S., Joel Studies (Uppsala: Lundequist 1948).

LeCureux, J.T., "Joel, the Cult, and the Book of The Twelve," Priests and Cults in the Book of the Twelve (ed. L.-S. Tiemeyer) (Ancient Near East Monographs 14; Atlanta, GA: SBL 2016) 65-79.

Limburg, J., Hosea-Micah (IBC Interpretation: A Bible Commentary for Teaching and Preaching; Atlanta, GA: Knox 1988).

Mallon, E. D., "Joel, Obadiah,” The New Jerome Biblical Commentary (Englewood Cliffs, NJ: Prentice-Hall 1990) 399-405.

Nogalski, J.D., "The Day(s) of YHWH in the Book of the Twelve," Thematic Threads in the Book of the Twelve (eds. P.L. Redditt - A. Schart) (Beihefte zur Zeitschrift für die alttestamentliche Wissenschaft 325; Berlin - New York: De Gruyter 2003) 192-213.

Ogden, G.S., "Joel 4 and Prophetic Responses to National Laments," Journal for the Study of the Old Testament 26 (1983) 97-106.

Ogden, G.S. - Deutsch, R.R., A Promise of Hope. A Call to Obedience. A Commentary on the Books of Joel and Malachi (International Theological Commentary; Grand Rapids, MI: Eerdmans 1987). 
Petersen, D.L., The Prophetic Literature. An Introduction (Louisville, KY: Westminster John Knox 2002).

Pettus, D.D., A Canonical-Critical Study of Selected Traditions in the Book of Joel (PhD Diss. Liberty University; Waco, TX 1992).

Prinsloo, W.S., The Theology of the Book of Joel (Beihefte zur Zeitschrift für die alttestamentliche Wissenschaft 163; New York: De Gruyter 1985).

Schwesig, P.-G., Die Rolle der Tag-JHWHs-Dichtungen im Dodekapropheton (Beihefte zur Zeitschrift für die alttestamentliche Wissenschaft 366; Berlin - New York: De Gruyter 2006).

Strazicich, J., Joel's Use of Scripture and the Scripture's Use of Joel. Appropriation and Resignification in Second Temple Judaism and Early Christianity (Biblical Interpretation Series 82; Leiden - Boston, MA: Brill 2007).

Sweeney, M.A., Isaiah 1-39 with an Introduction to Prophetic Literature (Grand Rapids, MI: Eerdmans 1996).

Sweeney, M.A., "The Place and Function of Joel in the Book of the Twelve," Thematic Threads in the Book of the Twelve (eds. P.L. Redditt - A. Schart) (Beihefte zur Zeitschrift für die alttestamentliche Wissenschaft 325; Berlin - New York: De Gruyter 2003) 133-154.

Thompson, J.A. - Langford, N.F., "The Book of Joel. Introduction, Exegesis and Exposition," Interpreter's Bible (eds. G.A. Buttrick et al.) (New York - Nashville, TN: Abingdon 1956) VI, $727-760$.

VanGemeren, W.A., “The Spirit of Restoration,” Westminster Theological Journal 50 (1988) 81-102.

Watts, J.D.W., The Books of Joel, Obadiah, Jonah, Nahum, Habakkuk and Zephaniah (Cambridge: Cambridge University Press 1975).

Wolff, H.W., Dodekapropheton. II. Joel und Amos (Biblischer Kommentar. Altes Testament 14; Neukirchen-Vluyn: Neukirchener 1969). 